Editorial

\title{
Analyzing the EU Refugee Crisis: Humanity, Heritage and Responsibility to Protect
}

\author{
Amelia Hadfield ${ }^{1, *}$ and Andrej Zwitter ${ }^{2}$ \\ ${ }^{1}$ School of Psychology, Politics and Sociology, Canterbury Christ Church University, Kent, CT1 1QU, UK; \\ E-Mail: amelia.hadfield@canterbury.ac.uk \\ ${ }^{2}$ Faculty of Law, University of Groningen, 9712 EK Groningen, The Netherlands; E-Mail: a.zwitter@rug.nl \\ * Corresponding author
}

Submitted: 5 November 2015 | Published: 12 November 2015

\section{Keywords}

crisis; Europe; refugee; responsibility to protect

\section{Issue}

This editorial is part of a regular issue of Politics and Governance, edited by Andrej J. Zwitter (University of Groningen, The Netherlands) and Amelia Hadfield (Canterbury Christ Church University, UK).

(C) 2015 by the authors; licensee Cogitatio (Lisbon, Portugal). This article is licensed under a Creative Commons Attribution 4.0 International License (CC BY).

\section{Introduction}

2015 has shaken the EU to its core. Hard upon the heels of geopolitical upheavals in Ukraine, as well as internal battles to define both Eurozone and energy governance, the refugee crisis has prompted a sober reckoning of the EU's competence and its humanity. With an increasing number of articles and Special Issues in Politics and Governance focusing upon key aspects of the EU as both a political actor, and a source of governance, our autumn 2015 editorial looks briefly at the significance of the refugee crisis in the context of the EU's current response and future options.

It is difficult to write dispassionately about crises. Crises prompt anxiety about their cause, alarm about their impact and ongoing unease about an appropriate policy response. In responding to a crisis, the term 'policy' suggests a measured, synthesizing stance brought effectively to bear upon the salient parts of a given problem. Championed by a given political actor, and operationalised as a form of governance, policy responses have the potential to be focused, swift, targeted and effective. If only it were so easy in practice.

Political responses to the crises within the Union have accordingly been largely crafted on national, rather than Union perspectives. British PM David Camer- on for instance viewed the issue through the lenses of unemployed migrants and alleged claimant abuses within the British welfare system. His French and German counterparts meanwhile responded on the basis of their traditional view of EU and non-EU immigrants as overall net contributors to the welfare system, and ultimately a cultural positive. Even starker contrasts were witnessed as the crisis wore on. In his State of the Union speech, European Commission President JeanClaude Juncker argued that the vast majority of the 500,000 refugees heading to Europe were 'fleeing from war in Syria, the terror of the Islamic State in Libya or dictatorship in Eritrea', targeting Greece, Hungary and Italy (Juncker, 2015). In contrast to the razorwireinspired, proto-patriotic response of Hungarian President Viktor Orban, replete with alarmist imagery of migrants breaking down the doors of Europe, Juncker argued credibly that it was 'time for bold, determined and concerted action by the European Union, by its institutions and by all its Member States.' Juncker's argument was clear enough. Despite having become a victim of its own success, the Nobel-prize winning EU needs to rethink the practical implications of operating as a normative, ethical power. Juncker's words are worth revisiting at some length:

This is first of all a matter of humanity and of hu- 
man dignity. And for Europe it is also a matter of historical fairness. We Europeans should remember well that Europe is a continent where nearly everyone has at one time been a refugee. Our common history is marked by millions of Europeans fleeing from religious or political persecution, from war, dictatorship, or oppression.... Have we really forgotten that after the devastation of the Second World War, 60 million people were refugees in Europe? That as a result of this terrible European experience, a global protection regimethe 1951 Geneva Convention on the status of refugees-was established to grant refuge to those who jumped the walls in Europe to escape from war and totalitarian oppression?....Yet, in spite of our fragility, our self-perceived weaknesses, today it is Europe that is sought as a place of refuge and exile. It is Europe today that represents a beacon of hope, a haven of stability in the eyes of women and men in the Middle East and in Africa. That is something to be proud of and not something to fear. (Juncker, 2015, italics added)

Here too, imagery is key, largely because of the categories that arise in attempting to bring order to a crisis, and which subsequently play a key mode in constructing policy responses. Refugees and 'genuine' asylum-seekers from visibly volatile states inhabit one end of the 'refugee crisis' while demographic and market imbalances producing economic migrants have created the 'migration crisis'. The former are to be afforded protection because the arbitrary and violent nature of their home states cannot. The latter, at the mercy of general economic disparities rather than outright persecution, cannot - at least in multitudinous form - yet be guaranteed entry, or possibly even assistance. To some, these are specious distinctions; to others, the basis for an emergent if piecemeal European Agenda on Migration. This Agenda, on the basis of the European Commission's Second Implementation Package proposes-inter alia-a new crisis relocation mechanism, additional funding, reception centres, and amending a 2013 regulation 'establishing the criteria and mechanisms for determining the Member State responsible for examining an application for international protection lodged in one of the Member States by a third country national or a stateless person' (European Economic and Social Committee, 2015).

Is this good enough? Indeed, it is quite simply: enough? Observing the lack of agreement amongst EU member states, the inaction of the European Union itself, and the increasingly negative tone of political debates in various national media against refugees and migrants alike, one must ask what form current and future refugee crises will take, the nature of the demographic volatilities that give rise to them, and critically, the legal and ethical responsibilities of the EU. At a basic level, the migration crisis is no different from the myriad policy challenges that have arisen in the past few years; i.e. it illustrates once again the EU's limita- tions to jointly perceive problems in common and respond collectively. Problems in recognizing the intrinsic limits of 'Europe' and the necessity for a Union-wide response occur when the most sensitive aspects of Member States are at stake: their sovereignty, their borders, and their identity. For better or worse, migration challenges EU Member States to act as a group, generating zero-sum responses about their quantitative ability to economically support migrations, and exclusivist logic about their qualitative power to socially integrate migrants, regardless of their economic or asylum-based needs.

The EU's obligations are better understood by appreciating the complications of its own neighbourhood. Externally, the migration of entire communities toward Europe is traceable to roughly half a dozen key sources: (1) ongoing post-Arab Spring volatilities in North Africa; (2) the current failed state of post-intervention Libya; (3) the political and environmental consequences of Sahel-based fundamentalism upon North and East Africa; (4) the ongoing upheavals of the Middle East; (5) uneven post-conflict settlement in Afghanistan; (6) the impact of the Syrian civil war; and (6) recent ISIS incursions into Syria and Iraq. Much of this volatility predates the EU's own foreign policy structure, outflanks its limited strategic depth and is attributable to American and coalition-based incursions that have been more than a decade in the making. However, the demographic outcomes are increasingly and materially felt by the EU alone.

The 2015 EU Strategic Review, entitled The European Union in a changing global environment: A more connected, contested and complex world (forming part of the 2016 Global Strategy composed by the High Representative for Foreign Affairs and Security Policy Federica Mogherini) acknowledges that Europe's challenging global environment, in which 'fragile states and ungoverned spaces' have produced suffering, 'instability and violence...poverty, lawlessness, corruption and conflict-ridden electoral politics' resulting in the displacement of 50 million people (European External Action Service, 2015).

As described by the Strategic Review, the contrast between war-torn regions and the relative safety of the EU could not be more stark. The European Union has transformed from being merely alluringly hearth-like for economic migrants to the only remaining safe haven within reach for political refugees. Regardless of the cause, migrants collectively leave homes, property, livelihoods and family to undertake the grim risks associated with trafficking across both land and sea, and the ensuing vulnerability of fending for themselves upon arrival in an EU Member State. Those who survive then enter both a legal purgatory, and the absurdity of Europe's charitable resentment.

The fallout of Europe's neighbourhood, and the collateral damage in human terms has been a clear trend 
for the better part of five years; clear enough for key EU policy documents to identify it. Yet this summer, Europe delayed. Abstained. Waited. For death tolls to rise; for collective tragedies to break upon European shores; for localized dramas between the UK and France to herald a wider pressure against southern and central eastern states. From within and without, EU policy on migration appeared inadmissibly tardy and inexcusably inhumane. In the plaintive tones of the New York Times: 'It may seem quaint to recall the European Union's ideals; it is also necessary to its survival. Where is the statesman's voice that rises above the pusillanimous chorus of petty calculation and selfregard?' (Cohen, 2015). Only German's Chancellor Merkel appeared to grasp the humanity amidst the severity, the grief amidst the gravity. The European Union 'does not have the luxury of turning inwards', asserts the 2015 Strategic Review, and yet the EU still divides its perspective between 'a responsibility to protect our citizens' and a need to promote 'our interest and universal values' which, alongside European prosperity, are precisely the magnets transforming Europe into the sole safe haven for hundreds of thousands (European External Action Service, 2015).

What the 2015 Strategic Review suggests, and what Juncker asserted is roughly one and the same. Europe's heritage seems firmly established, yet its present humanity is in doubt. From a legal perspective, a key source of this rupture is the translation of essentially ethnocentric norms of human rights, rule of law, democracy and good governance into operable standards of behavior, specifically within Europe's own neighbourhood. Despite the soft power attraction inherent in enlargement, and the attempts by its lacklustre successor, the European Neighbourhood Policy, EU norms have ironically proved robust enough to help source post-war international law, but not attractive enough to transform the political outlook of its neighbourhood. Rather than the ring of 'well governed countries' that Javier Solana espoused in the 2003 European Security Strategy, post-enlargement regional upheavals in North Africa, the Middle East and Eastern Europe have thwarted both bilateral and multilateral attempts by the EU to establish a settled neighborhood on the principle of 'enlargement lite'. Instead of strategies to reduce conflict and mitigate insecurity, neither the ENP nor its core value-set have worked to transform any of the neighbourhood states, at least according to the ENP's initial template of governance. Instead, a combination of cultural specificity preventing a common interpretation of those norms, and national and fundamental upsurges inhibiting their implementation has marked the entire region.

For those who see the ENP as a form of remotecontrol foreign policy designed to prevent volatility and migratory shockwaves from spreading, then European humanity came instrumentally adrift from its heritage the moment the policy was launched. For those who regarded the ENP as a long-term, incentive-driven form of variable integration, the norms designed to level the political, economic and civil society playing fields eroded more slowly, seeping away with each iteration that transformed itself, rather than its neighbours, from the principle of 'more for more' to a guarantee of 'less for less'.

Civilizationally, the ethical responsibility of the EU is to move from its Westphalian heritage to spreading the lessons of both World Wars. This requires transforming communitarian structures in which national communities remain purely coextensive with their borders, and retain exclusivist policy attitudes to cosmopolitan structures in which the ethical significance of key norms strikes a balance with state autonomy internally and externally condone general standards of justice, fairness and moral reasonableness. The transcendence of political statism through normative community, in other words. By dint of institutional, legal, economic and political integration, many aspects of EU governance have now transformed statist perspectives to cosmopolitan structures. We have also seen slow but perceptible shifts from exclusivist interpretations of sovereignty to the establishment of international society upon the basis of law, the maintenance and pursuit of peace and the common goals of a social life: the central elements identified by international relations scholar Hedley Bull (1977) regarding the morality of contemporary states. From this perspective, despite the EU's failure to support key neighbourhood states or support their societies during post-war turbulence, the EU has an established record in terms of uploading its normative heritage to the international level, both as a key member of the international community, and as a central player in the construction of key aspects of post-war international law. The EU is therefore identified and indeed appreciated as a normative actor, with a strong reputation for supporting key values, specifically democracy and human rights. The difficulty of course is how to go beyond the technical, diplomatic economic support of values, and construct policies that actually establish rather than espouse value-based reforms. Human rights, for instance remains the responsibility of every state as confirmed by the International Commission on Intervention and State Sovereignty (ICISS), which from 2001 has promulgated the principle of state-led humanitarian intervention and democracy restoration known as the 'responsibility to protect' (Council on Foreign Relations, 2001).

In this respect, the problem for the EU (as for other cosmopolitan actors) is the observance and enforcement of human rights in the face of breaches. As suggested in the Commission's report on The Responsibility to Protect (International Commission on Intervention and State Sovereignty, 2001), enforcement is itself a right, particularly where breaches entail crimes against humanity, war crimes, crimes of aggression, and the crime of genocide. While the ability, and 
indeed the ex ante responsibility to prevent such crimes has yet to be established beyond episodic modes of international behavior, the ex post responsibility to afford a duty of care to those affected by way of postconflict protection and reconstruction remains ironically both opaque and obligatory. Such responsibilities are essential, whether intervention has destroyed infrastructure and livelihoods, or whether the complete absence of assistance has forced countless communities to relocate. The irony is that for the EU, while norms are deeply embedded (if somewhat unevenly upheld) in its domestic makeup, the humanitarian obligations that flow from the observance of these same norms in its neighbourhood contexts are not yet evenly implemented.

Is this simply because the neighbourhood remains fundamentally outside, quintessentially beyond the EU, rather than a fundamental part of the context by which the Union is at once constructed and in the process of constructing? A neighbourhood that is associated with the Union, but not yet of Europe, and consequently entailing differential, but fundamentally different treatment? While its intervention in the Balkans is largely a positive story of post-conflict reconstruction and support, EU assistance in states that have for more than a decade fallen within strategic contours of its own European Neighbourhood Policy has been lackluster at best and non-existent at worst. Georgia and Ukraine in the east, Lebanon and Syria in the Middle East, Libya and Egypt in North Africa all exemplify areas where the $\mathrm{EU}$, and other key powers have simply defaulted in their responsibility to protect and rebuild. Bottom-up, civil society-based resilience remains preferable to topdown political support (or resistance), the prevalent strategy being to keep out of conflicts and supporting foreign policy protagonists at arm's length (e.g. Palestine, the Kurds, much of the Ukraine and the majority of civil society in ENP states).

The problem with this approach is twofold. First, one abdicates responsibility for tackling the proximate problem directly. True, the appetite and political will to bring an antagonist to ground is frequently in abeyance. The consequences for failing to do so however, are anything but: protracted inaction permit statebased tyrannies to operate with impunity, while repressive non-state regimes like ISIS to expand their reach rapaciously. Second, in abjuring responsibility to tackle (or even to unequivocally name) the initial cause of a conflict, it is alarmingly easy to then neglect the remote, ex post consequences of affording protection to the human communities living within, or shifting desperately to avoid a given conflict. Having deflected the responsibility to engage in any significant way (or in any particular geopolitical combination), with much of the above-mentioned causes of neighborhood upheaval, Europe is now experiencing the consequences of precisely this omission in the form of massive refugee flows. The second omission, that of failing to fulfill even a basic responsibility to protect societies within those countries most at risk of demographic upheaval has this summer led to a third infraction: neglecting to afford a collective duty of care to the refugees fleeing as a direct response of inaction and lack of assistance by key global actors, including the EU. In instances where return is impossible, either in the short or long term, the responsibility to rebuild must at a minimum be replaced by the responsibility to receive, preferably as an accepted component of EU foreign policy if not as a principle of international law.

While moral rightness and legality remain on different footings, the majority of national legislation, including the EU's proposed migration mechanisms fall far short of their ethical responsibilities. To remedy such problems, the legal philosopher, Gustaf Radbruch, has suggested that preference be 'given to the positive law, duly and secured by state power as it is, even when it is unjust and of no benefit to the people, unless its conflict with justice reaches so intolerable a level that the statute becomes, in effect, 'false law' and must therefore yield to justice (Radbruch, 1946; Radbruch as cited in Paulson, 1995). Within the context of the refugee crisis, one may well conclude that the EU, and its Member States are facing precisely this challenge: injustice and human suffering are indeed reaching intolerable levels, thus the present legal corpus must somehow yield to the principled and justiciable needs of humanity.

In terms of immediate policy change, as well as future types of governance, the ENP is surely in need of radical overhaul if it is to guarantee the continuity of EU stability internally, and neighbourhood security externally. The ENP remains the most paradoxical of all EU foreign policies: designed to domestic its foreign neighbourhood precisely by denying the domesticating influence of full accession; the promise of EU partnership but based on the partner's own promises. Having signally failed to make good the principle of neighbour, partner or even associate, the EU is being forced to internalize the external pressure of refugees and migrants in both practical and cultural terms. The ENP however was not designed as a regional preventative but rather an incentive-driven package. Despite this, while much local and regional upheaval could not have been prevented, its causes, and certainly its effects in societal terms, could have been predicted. Even its most recent appraisal acknowledges that the 'ENP has not always been able to offer adequate responses to these recent developments, nor to the changing aspirations of our partners. Therefore, the EU's own interests have not been fully served either' (High Representative of the European Union for Foreign Affairs and Security Policies, 2015).

What is therefore crucial for the political actor of the $\mathrm{EU}$, and its subsequent governance of the neighbourhood, is that the next overhaul of the ENP is (1) clear from the outset about the migratory shifts that will become a staple of Europe's neighbourhood for 
decades to come; (2) offer rationalized Union-based support to refugees in transit and upon arrival of all stripes; and (3) targeted responses based on the responsibility to protect and rebuild in the absence of, but preferably in counterpart with substantive political interventions. European leaders have so far failed to recognize, in the words of the late Tony Judt, "how much change was needed if you wished to keep the important things as they were'; the challenge therefore being to strike a balance between the possible and the necessary (Judt \& Snyder, p. 7). Some acknowledgment of the possible tools needed to ensure the necessary result is found in the above-mentioned Strategic Review, in which 'redoubling commitment to our European neighbours' provides a range of options, all bent on promoting structural economic and positive political reform 'through credible policies of integration and association' (European External Action Service, 2015). The next step however is to ensure that the suggestions in this report, and those in the 2016 EU Global Strategy obtain materially as policy tools that are practical to deploy and efficient to run in ENP partner states, specifically in terms of conflict resolution, and cross-border migratory issues.

Failing to do so will not only deepen the refugee crisis, it will relegate the ENP from being merely discredited to emphatically deceased. If humanity is to actively determine the nature of European governance, rather than passively reflecting its heritage, then Juncker's State of the Union admonition is crucial: 'We Europeans should know and should never forget why giving refuge and complying with the fundamental right to asylum is so important. I have said in the past that we are too seldom proud of our European heritage and our European project' (Juncker, 2015). While for many, the EU remains 'the dullest miracle on earth', it is also the single greatest achievement of one of the most war-torn centuries in human history (Cohen, 2015). In advancing a migratory policy that is both ethical and utilitarian, the EU now needs to realign its internal odyssey with its regional destiny.

\section{Conflict of Interests}

The authors declare no conflict of interests.

\section{References}

Bull, H. (1977). The anarchical society: A study of order in world politics. New York City, NY: Columbia University Press.

Cohen, R. (2015, August 7). Europe without ideas is a dangerous thing. New York Times.

Council on Foreign Relations. (2001). International commission on intervention and state sovereignty: Responsibility to protect. New York: CFR.

European Economic and Social Committee. (2015). European agenda on migration: Second implementation package (COM(2015) 450 final). Brussels: European Commission. Retrieved from http://www. eesc.europa.eu/?i=portal.en.soc-opinions.37296

European External Action Service. (2015). EU strategic review: The European Union in a changing global environment: A more connected, contested and complex world. Brussels: EEAS. Retrieved from http://eeas.europa.eu/docs/strategic_review/eustrategic-review_strategic_review_en.pdf

High Representative of the European Union for Foreign Affairs and Security Policies. (2015, March 3). Joint consultation paper: Toward a new European Neighbourhood Policy. (JOIN (2015) 6 final). Brussels: European Commission. Retrieved from ec.europa. eu/enlargement/neighbourhood/consultation/cons ultation.pdf

International Commission on Intervention and State Sovereignty. (2001). The Responsibility to protect. New York: International Coalition for the Responsibility to Protect. Retrieved from http://responsi bilitytoprotect.org/ICISS\%20Report.pdf

Judt, T., \& Snyder, T. (2013). Thinking the twentieth century. London, UK: Vintage Books.

Juncker, J. C. (2015, September 9). State of the Union: Time for honesty, unity and solidarity. Strasbourg: European Union. Retrieved from http://europa. eu/rapid/press-release_SPEECH-15-5614_en.htm

Paulson, S. L. (1995) Radbruch on unjust laws: Competing earlier and later views? Oxford Journal of Legal Studies, 15(3), 490.

Radbruch, G. (1946). Gesetzliches Unrecht und übergesetzliches Recht. Scweizerische Juristen-Zeitung/ Revue Suisse de Jurisprudence, 107.

\section{About the Authors}

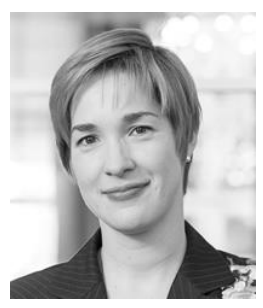

Dr. Amelia Hadfield

Amelia Hadfield is Reader in European Foreign Affairs in Politics \& International Relations Programme at Canterbury Christ Church University, having previously worked at the University of Kent, the Vrije Universiteit and the Institute for European Studies (Brussels). Amelia is the CCCU Jean Monnet Chair in European Foreign Affairs, Director of the Energy and Governance Group, and a Senior Fellow of the UK Higher Education Academy. 


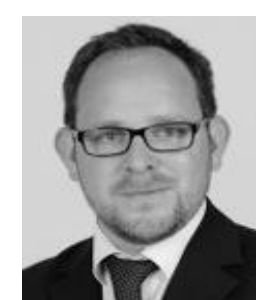

\section{Dr. Andrej Zwitter}

Prof. dr. iur. Andrej Zwitter holds the NGIZ Chair in International Relations within the Faculty of Law at the University of Groningen and is also a co-Chair of Research in Ethics and Globalization. He furthermore is a Senior Research Fellow at Liverpool Hope University. He heads the Political Sciences Department at the Faculty of Law. His current research foci include the law and politics of humanitarian action and national emergency management and ethics in international politics as well as Big Data. 